\title{
Hemoglobin curves during pregnancy before and after fortification of flours with iron*
}

\author{
CURVAS DE HEMOGLOBINA AO LONGO DA GESTAÇÃO ANTES E APÓS A \\ FORTIFICAÇÃO DE FARINHAS COM FERRO
}

\author{
CURVAS DE HEMOGLOBINA DURANTE EL EMBARAZO ANTES Y DESPUÉS DE LA \\ FORTIFICACIÓN DE LA HARINA CON HIERRO
}

\section{Ana Paula Sayuri Sato ${ }^{1}$, Elizabeth Fujimori², Sophia Cornbluth Szarfarc ${ }^{3}$}

\begin{abstract}
Objective: To assess the level of hemoglobin- $\mathrm{Hb}$ during pregnancy before and after fortification of flours with iron. Method: A cross-sectional study with data from 12,119 pregnant women attended at a public prenatal from five macro regions of Brazil. The sample was divided into two groups: Before-fortification (birth before June/2004) and After-fortification (last menstruation after June/2005). Hb curves were compared with national and international references. Polynomial regression models were built, with a significance level of $5 \%$. Results: Although the higher levels of $\mathrm{Hb}$ in all gestational months after-fortification, the polynomial regression did not show the fortification effect $(p=0.3)$. Curves in the two groups were above the references in the first trimester, with following decrease and stabilization at the end of pregnancy. Conclusion: Although the fortification effect was not confirmed, the study presents variation of $\mathrm{Hb}$ levels during pregnancy, which is important for assistencial practice and evaluation of public policies.
\end{abstract}

\author{
DESCRIPTORS \\ Anemia, iron-deficiency \\ Pregnant women \\ Prenatal care \\ Maternal-child nursing \\ Food, fortified
}

\section{RESUMO}

Objetivo: Avaliar o nível de hemoglobina$\mathrm{Hb}$ ao longo da gestação antes e após a fortificação de farinhas com ferro. Método: Estudo transversal com dados de 12.119 gestantes atendidas em pré-natal público de municípios das cinco macrorregiões do Brasil. Formaram-se dois grupos: Antesfortificação (parto anterior a jun/2004) e Após-fortificação (última menstruação posterior a jun/2005). Curvas de $\mathrm{Hb}$ foram comparadas com referências nacional e internacional. Construíram-se modelos de regressão polinomial, com nível de significância de 5\%. Resultados: Apesar dos níveis superiores de $\mathrm{Hb}$ em todos os meses gestacionais após-fortificação, a regressão polinomial não mostrou efeito da fortificação $(p=0,3)$. As curvas dos dois grupos mostraram-se acima das referências no primeiro trimestre, com queda a seguir e estabilização no final da gestação. Conclusão: Apesar de não constatar efeito da fortificação, o estudo apresenta variação dos níveis de $\mathrm{Hb}$ durante a gravidez, importante para a prática assistencial e avaliação das políticas públicas.

\author{
DESCRITORES \\ Anemia ferropriva \\ Gestantes \\ Cuidado pré-natal \\ Enfermagem materno-infantil \\ Alimentos fortificados
}

\section{RESUMEN}

Objetivo: Evaluar el nivel de hemoglobina $\mathrm{Hb}$ ) durante el embarazo antes y después de la fortificación de la harina con hierro. Método: Estudio transversal con datos de 12.119 mujeres embarazadas que acuden a consultas prenatales públicas en municipios de las cinco macro-regiones de Brasil. Se formaron dos grupos: Antes de la Fortificación (parto antes de junio de 2004) y Después de la Fortificación (última menstruación después de junio de 2005). Las Curvas de $\mathrm{Hb}$ se compararon con referencias nacionales e internacionales. Se construyeron modelos de regresión polinomial, con nivel de significancia del 5\%. Resultados: A pesar de altos niveles de $\mathrm{Hb}$ en todos los meses Después de la Fortificación, la regresión polinómica no mostró efecto de la fortificación $(p=0,3)$. Las curvas de los dos grupos estaban por encima de las referencias en el primer trimestre, para luego caer y posteriormente estabilizarse al final del embarazo. Conclusión: Aunque no se observó efecto de la fortificación, el estudio muestra variaciones en los niveles de $\mathrm{Hb}$ durante el embarazo, lo que es importante para la práctica asistencial y la evaluación de las políticas públicas.

\author{
DESCRIPTORES \\ Anemia ferropénica \\ Mujeres embarazadas \\ Atención prenatal \\ Enfermería maternoinfantil \\ Alimentos fortificados
}

\footnotetext{
*Extracted from the thesis "Avaliação dos níveis de hemoglobina de gestantes brasileiras antes e após a fortificação de farinhas com ferro", Nursing School, Universidade de São Paulo, 2013. 'Doctor Professor, Epidemiology Department, Universidade de São Paulo, São Paulo, SP, Brazil. sah@usp.br ${ }^{2}$ Associate Professor, Department of Public Health Nursing, Nursing School, Universidade de São Paulo, São Paulo, SP, Brazil.
} ${ }^{3}$ Associate Professor, Public Health Faculty, Universidade de São Paulo, São Paulo, SP, Brazil. 


\section{INTRODUCTION}

Pregnancy is a particular moment in women lives, marked by innumerous physiological and anatomical adjustments in a short amount of time. The maternal plasmatic volume and the red cell mass expansion is necessary to produce fetal amniotic liquid, to increase the total capacity of blood connection with oxygen and to facilitate the distribution of oxygen in tissues ${ }^{(1)}$. Besides that, this increase attend the uterus hypertrophied vascular system demands to protect the mom and fetus from deleterious effects of drops in cardiac output and, specially, to protect the mother from blood losses associated with birth and puerperium ${ }^{(2)}$.

In women with an adequate iron nutritional state, the hemoglobin level $(\mathrm{Hb})$ starts to decline on the end of the first trimester and reaches the lowest value at the end of the second trimester $\left(24^{\text {th }}\right.$ to $32^{\text {nd }}$ weeks of pregnancy), with a discrete increase during the third trimester of pregnancy, explained by changes in plasmatic and red cell mass volume ${ }^{(3)}$. Due to the elevated demand of iron during pregnancy, the mineral drug supplement starting at the $20^{\text {th }}$ week of pregnancy it is part of pregnant care activities $^{(4)}$. However, anemia prevalence is still high, affecting about 30 to $40 \%$ of pregnant women, with great variability $^{(5-6)}$, and depending on the gestational trimester ${ }^{(7)}$.

Maternal anemia increases the risk of premature birth and low birth weight. A review study showed that severe anemia is associated with low weight newborn, consequence of prematurity or growth restriction ${ }^{(8)}$. There is also evidence of early detection and efficient anemia treatment during pregnancy being associated to anemia and infant/adolescent malnutrition reduction and improvements in height at adulthood ${ }^{(9)}$. Thus, the importance to evaluate anemia in prenatal assistance is reinforced.

Aiming to contribute to the anemia control in the country, the Brazilian Health Ministry instituted the compulsory fortification of wheat and corn flours with iron starting in July of $2004^{(10)}$. The measure effect in Brazilian pregnant women pointed to significant decrease in anemia prevalence, with significantly higher means of $\mathrm{Hb}$ after the fortification ${ }^{(11)}$, but the answer to this intervention was not analyzed, considering the physiological alterations during pregnancy and the increase of iron demands.

It is pertinent to evaluate the behavior of $\mathrm{Hb}$ levels during pregnancy months, before and after fortification of flours with iron, the objective of the present study.

\section{METHOD}

This study integrates a broad cross-sectional investigation conducted with retrospective data from records of 12,119 pregnant women attended in public prenatal services of 13 cities from the five geographical regions of Brazil. Pregnant women were divided in two groups: Before-fortification of flours with iron (pregnant women who gave birth before June of 2004), and After-fortification (pregnant women with last date of menstruation posterior to June of 2005).

Data collection was conducted during 2006 to 2008 and included only low risk pregnant women, whose records had at least the date of the first prenatal consultation and from the last menstruation and the $\mathrm{Hb}$ dosage.

The dependent variable was the $\mathrm{Hb}$ level (g/dL) and the independent variables were: group (Before and Afterfortification), geographical region, socio-demographic characteristics (age and relationship status), obstetric history (number of previous pregnancies and history of abortion) and prenatal characteristics (gestational age and nutritional state on the first prenatal consultation).

As the $\mathrm{Hb}$ data referred to the exam requested in the $1^{\text {st }}$ prenatal consultation, the present study assumed that pregnant women, even those in the second or third trimester, for not being prenatal followed until then, did not receive guidance to use the supplement, recommended from the $20^{\text {th }}$ week of pregnancy.

The levels of $\mathrm{Hb}$ in accordance with the gestational age were described through means, standard deviation and $95 \%$ Confidence Intervals. Hb curves following gestational age in months were built for the total pregnant women and stratified per fortification group. The Student $\mathrm{t}$ test was calculated to compare $\mathrm{Hb}$ means before and after fortification.

To adjust the $\mathrm{Hb}$ curves following the gestational month and the independent variables, polynomial regression models were built, being the dependent variable the level of $\mathrm{Hb}$. The modelling was done by regression technique, from the linear model to third order form. The model choice was based in the descriptive level $(p<0.05)$ and in the residual analysis, to verify the model significance and the homoscedasticity assumption, respectively. The level of significance in all tests was $5 \%$.

The $\mathrm{Hb}$ curves were compared to cut-off proposed by the World Health Organization (WHO) ${ }^{(12)}$ to identify anemia in pregnant women $(<11.0 \mathrm{~g} / \mathrm{dL})$ and with two curves, one international and one national. It was compared to the Centers for Diseases Control and Prevention (CDC) curve $^{(13)}$, which propose specific cut-off ( $5^{\text {th }}$ percentile) per gestational month for pregnant women supplemented with iron; and it was also compared to the $\mathrm{Hb}$ distribution model found in Szarfarc et al. ${ }^{(14-15)}$ studies with Brazilian pregnant women not supplemented with iron, using the $7^{\text {th }}$ percentile to establish risk.

The study was approved by the Ethics in Research Committee (Process no 521/2006).
Hemoglobin curves during pregnancy before and after fortification of flours with iron Sato APS, Fujimori E, Szarfarc SC 


\section{RESULTS}

Table 1 presents the levels of $\mathrm{Hb}$ in accordance with gestational month and fortification group. It was verified an important drop in both groups from the first gestational trimester. Levels of $\mathrm{Hb}$ were statistically more elevated in the After-fortification group ( $p<0.005)$, in all months, except at the beginning ( $<3^{\text {rd }}$ month) and at the end ( $8^{\text {th }}$ month).

Table 1 - Mean, standard deviation and 95\% CI of Hb levels in accordance with gestational month and Before and After fortification groups, Brazil, 2006 to 2008.

\begin{tabular}{|c|c|c|c|c|c|c|c|}
\hline \multirow{2}{*}{ Month } & \multicolumn{3}{|c|}{ Before-fortification } & \multicolumn{3}{|c|}{ After-fortification } & \multirow{2}{*}{ p-value* } \\
\hline & $\mathbf{n}$ & Mean (SD) & CI95\% & $\bar{n}$ & Mean (SD) & CI95\% & \\
\hline$<3$ & 803 & $12.53(1.18)$ & $12.45-12.61$ & 980 & $12.54(1.12)$ & $12.47-12.61$ & 0.197 \\
\hline 3 & 1406 & $12.21(1.14)$ & $12.15-12.27$ & 1575 & $12.30(1.17)$ & $12.24-12.36$ & 0.029 \\
\hline 4 & 1235 & $11.76(1.18)$ & $11.69-11.83$ & 1284 & $11.90(1.14)$ & $11.83-11.96$ & 0.003 \\
\hline 5 & 935 & $11.43(1.17)$ & $11.36-11.51$ & 869 & $11.56(1.11)$ & $11.48-11.63$ & 0.025 \\
\hline 6 & 540 & $11.21(1.16)$ & $11.11-11.31$ & 495 & $11.36(1.12)$ & $11.26-11.46$ & 0.035 \\
\hline$\geq 8$ & 447 & $11.22(1.16)$ & $11.11-11.33$ & 330 & $11.33(1.19)$ & $11.20-11.46$ & 0.200 \\
\hline
\end{tabular}

*The $p$-value is referred to Student $t$ test.

Through a cubic polynomial regression model (Table 2), the $\mathrm{Hb}$ adjusted curve was estimated by gestational month (Figure 1). The fortification was found not statistically significant in the multiple model, independently of the geographical region, age, relationship status, BMI in the first prenatal consultation and number of previous pregnancies, variables significantly associated to $\mathrm{Hb}$ levels (Table 2 ).

Table 2 - Polynomial model parameter for mean levels of $\mathrm{Hb}$ in accordance with gestational month, fortification group, geographical region, age, relationship status, BMI and number of previous pregnancies, Brazil, 2006 to 2008.

\begin{tabular}{|c|c|c|}
\hline \multirow{2}{*}{ Variables } & \multicolumn{2}{|c|}{ Total } \\
\hline & $\beta$ & p-value \\
\hline Gestational month & 0.398 & 0.036 \\
\hline${\text { (Gestational month })^{2}}^{2}$ & -0.181 & $<0.001$ \\
\hline${\text { (Gestational month })^{3}}^{3}$ & 0.015 & $<0.001$ \\
\hline \multicolumn{3}{|l|}{ Group } \\
\hline Before-fortification & Reference & \\
\hline After-fortification & 0.03 & 0.316 \\
\hline \multicolumn{3}{|l|}{ Geographical region } \\
\hline Northeast & Reference & \\
\hline North & 0.153 & 0.016 \\
\hline Midwest & 0.062 & 0.401 \\
\hline Southeast & 0.332 & $<0.001$ \\
\hline South & 0.813 & $<0.001$ \\
\hline Age (years) & 0.008 & 0.005 \\
\hline \multicolumn{3}{|l|}{ Relationship status } \\
\hline With partner & Reference & \\
\hline Without partner & -0.123 & $<0.001$ \\
\hline BMI in the $1^{\text {st }}$ consultation $\left(\mathrm{kg} / \mathrm{m}^{2}\right)$ & 0.024 & $<0.001$ \\
\hline \multicolumn{3}{|l|}{ Previous pregnancies } \\
\hline$<2$ & Reference & \\
\hline$\geq 2$ & -0.239 & $<0.001$ \\
\hline Adjusted R ${ }^{2}$ & \multicolumn{2}{|c|}{0.223} \\
\hline F (p-value) & \multicolumn{2}{|c|}{$121.280(<0.001)$} \\
\hline
\end{tabular}

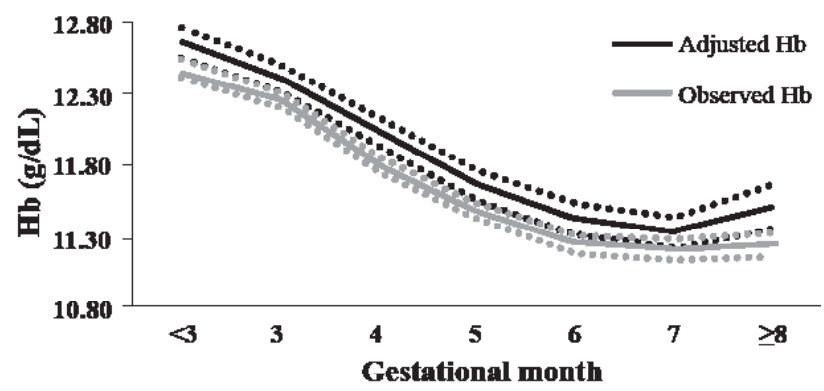

Figure 1 - Hb curves by gestational month, observed and adjusted for fortification group, geographical region, age, relationship status, BMI, previous pregnancies, Brazil, 2006 to 2008.

The $\mathrm{Hb}$ curve for the studied pregnant women was compared to the WHO cut-off and with the two curves, international (CDC) and national (Szarfarc et al.) (Figure 2).

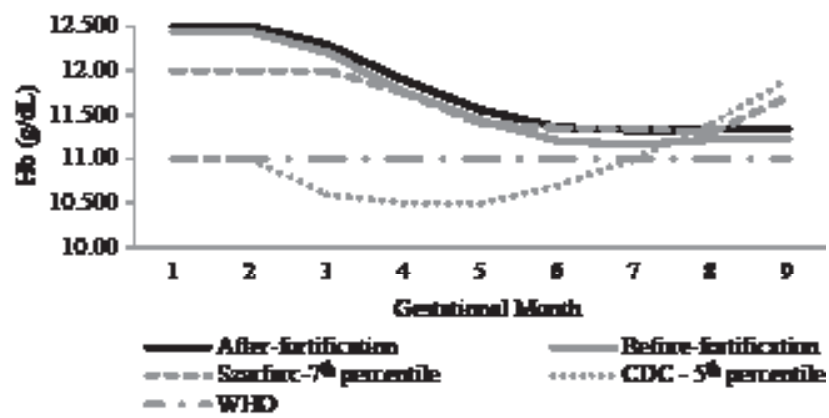

Figure 2 - Comparison of $\mathrm{Hb}$ curves before and after fortification with the five Szarfarc et al., CDC and WHO critical levels, Brazil - 2006 to $2008^{(12-14)}$.

Figure 2 shows that in the $1^{\text {st }}$ gestational trimester both groups, Before and After-fortification presented superior $\mathrm{Hb}$ levels to the critical levels of reference curves. The Before-fortification group reached Szarfarc et al. critical levels at six months, and kept like that until the end of pregnancy. In the Before-fortification group, the drop in $\mathrm{Hb}$ levels reached Szarfarc et al. critical levels from the fifth month, but they kept higher than the WHO cut-off. 
However, it is important to note that the levels of $\mathrm{Hb}$ from both studied groups did not follow the increase in $\mathrm{Hb} \mathrm{lev-}$ els observed in the CDC curve from the $7^{\text {th }}$ month, nor the Szarfarc et al. curve from the $8^{\text {th }}$ month.

\section{DISCUSSION}

The results showed higher $\mathrm{Hb}$ levels in the After-fortification group in all gestational months, except at the beginning ( $<3^{\text {rd }}$ month) and at the end ( $\geq 8^{\text {th }}$ month), without statistically significant difference by the polynomial regression model, a result suggesting absence of effect from the fortification of flours with iron in the $\mathrm{Hb}$ level through the pregnancy of Brazilian women.

Although the food fortification is positively evaluated in many countries, this assertive is not clear for the iron fortification ${ }^{(16)}$. Besides, the real effects of this policy are not yet clear and must be considered, once declines in the anemia prevalence can result in structural changes in life conditions and, therefore, in the food offer, in eating patterns and in the improvement of access to health services.

It should be added the need for conjunct interventions to reduce iron deficiency anemia in the country, to recommend nutritional education, drug supplement and food fortification with iron.

A study conducted in United States of America (USA) aiming to quantify the potential effect of food fortification with iron, used models to build a simulation capable of separate the fortification effects from other variables, as the provision of food and eating habits, it was found that without the fortification, the iron deficiency anemia would increase from 2 to $5 \%$ between pre-scholars, adolescent girls and women in reproductive age. Thus, it would not have effect in men, women or children of all other age groups ${ }^{(17)}$.

Brazilian studies presented two hypotheses for the low effectiveness of flour fortification in the country. The first refers to the low consumption of fortified food, reiterated in the Survey of Family Budgets POF (2004), especially within the low income population $(<2$ minimum wage/family). The second aspect is related to the low bioavailability of iron compounds that are being used in the fortification and its absorption suffers elevated influence of inhibitors for its utilization ${ }^{(11,18)}$.

To evaluate the levels of $\mathrm{Hb}$ through pregnancy is fundamental, once its difference in the anemia prevalence estimate can be a result of gestational age variability in the moment of the blood exam ${ }^{(19)}$.

The important drop in $\mathrm{Hb}$ levels observed from the first trimester of pregnancy is a behavior confirmed in other studies ${ }^{(20-22)}$, including in the $\mathrm{Hb}$ distribution model of Brazilian pregnant women ${ }^{(14)}$ and also in international level(13). Those changes suggest for anemia diagnose to consider specific $\mathrm{Hb}$ values in accordance with the gestational month ${ }^{(3,13)}$. Thus, a study with healthy Danish women pointed as $\mathrm{Hb}$ critical levels $11.0 \mathrm{~g} / \mathrm{dL}$ in the first trimester and $10.5 \mathrm{~g} / \mathrm{dL}$ in the second and third trimesters of pregnancy ${ }^{(22)}$.

However, it is important to note that $\mathrm{Hb}$ levels in both studied groups did not follow the increase in $\mathrm{Hb}$ levels observed in the CDC curve from the $7^{\text {th }}$ month, nor the Szarfarc et al. curve from the $8^{\text {th }}$ month. This result could be explained by the fact that studied pregnant women did not receive ferrous sulfate, while the pregnant women composing the CDC curve were supplemented with iron. Besides, as the present study sample was scarce at the end of pregnancy, after the $8^{\text {th }}$ month, an average of $\mathrm{Hb}$ levels was considered, a fact that possibly did not allow to identify an increase in the $\mathrm{Hb}$ level after the $8^{\text {th }}$ month between the studies pregnant women, as observed in the literature ${ }^{(14-15)}$.

Thus, the results from the present study represented important information, once there is no nationwide research that present $\mathrm{Hb}$ curves along pregnancy. The available data refers only to estimates based in punctual studies. Therefore, although the present study sample was not randomized for all country, the obtained data from 12,119 pregnant women accurately represents changes in $\mathrm{Hb}$ levels during pregnancy of Brazilian women that can be considered for practical assistance.

Moreover, the study population was composed by women assisted in public health services, referred to a higher risk group of women regarding nutritional deficiencies and with health services restricted access in the Brazilian Unified Health System. The services demands and the availability of resources, limit many times, the number of consultations and the complete fulfillment of the protocol, as well as the careful reading of described data in the complete blood count. Besides, because this population is more vulnerable for presenting fragile socioeconomic indicators, it is subjected to nutritional deficiencies as a whole and not only iron deficiency anemia, than those with access to private services, therefore, they have better socio-economic indicators.

Because anemia is conceptualized by $\mathrm{Hb}$ levels, this indicator is, especially within pregnant women, a fundamental parameter to investigate an intervention effect in the prevention and control.

The Brazilian health system guarantee prenatal coverage for all pregnant women and includes $\mathrm{Hb}$ dosage in the first prenatal consultation and also at the end of pregnancy ${ }^{(4)}$, allowing anemia control, which made possible this study based in medical records. Although the use of secondary data represents a limitation aspect due to the quality of information not always standardized, the use of those information allow to evaluate a high number of pregnant women.
Hemoglobin curves during pregnancy before and after fortification of flours with iron Sato APS, Fujimori E, Szarfarc SC 
As a modifiable risk factor, maternal nutritional state is fundamental in terms of primary care and therefore, should be integrated to prenatal assistance by health professional as prevention strategy of adverse outcomes in birth, particularly in developing countries ${ }^{(8)}$. In this scenario, the nurse as acting member in the prenatal assistance team ${ }^{(23)}$ can effectively contribute to the prevention and treatment of anemia during pregnancy, as the nursing consultation is an important tool for anemia prevention, identification and control ${ }^{(24)}$.

\section{CONCLUSION}

The $\mathrm{Hb}$ level presents an important drop from the first trimester in both groups, but the After-fortification curve kept above the Before-fortification group. The polynomial regression, however, did not show significant effect for the fortification of flours with iron. Besides that, the $\mathrm{Hb}$ curves of both groups were above the national and international references in the first trimester, with a following drop and stabilization at the end of pregnancy which did not follow the increase in reference $\mathrm{Hb}$ levels.

Although the iron fortification effect in flours was not found, it is highlighted as a merit of the present study the importance to consider the variation in $\mathrm{Hb}$ levels along pregnancy. It is also presented a baseline of $\mathrm{Hb}$ levels by gestational month that can be used to evaluate levels of $\mathrm{Hb}$ in Brazilian pregnant women, once the $\mathrm{Hb}$ level varies during pregnancy as an answer to the high demand of iron. Moreover, the study provides subsidies for public policy evaluation of anemia control, contributing to the improvement and planning of new interventions.

\section{REFERENCES}

1. Lee Al, Okam MM. Anemia in pregnancy. Hematol Oncol Clin North Am 2011;25(2):241-59.

2. Souza Al, Batista Filho M, Ferreira LOC. Alterações hematológicas e gravidez. Rev Bras Hematol Hemoter. 2002;24(1):29-36.

3. Milman N. Iron and pregnancy: a delicate balance. Ann Hematol. 2006;85(9):559-65.

4. Brasil. Ministério da Saúde; Secretaria de Atenção à Saúde, Departamento de Atenção Básica. Atenção ao pré-natal de baixo risco. Brasília; 2012

5. Batista Filho M, Souza AI, Bresani CC. Anemia como problema de saúde pública: uma realidade atual. Ciênc Saúde Coletiva. 2008;13(6):1917-22.

6. Côrtes MH, Vasconcelos IAL, Coitinho DC. Prevalência de anemia ferropriva em gestantes brasileiras: uma revisão dos últimos 40 anos. Rev Nutr. 2009;22(3):409-18.

7. Fujimori E, Sato APS, Araújo CRMA, Uchimura TT, Porto ES, Brunken GS, et al . Anemia in pregnant women from two cities in the South and Mid-West Regions of Brazil. Rev Esc Enferm USP [Internet]. 2009 [cited 2014 Jan 22];43(n. spe2):1204-9. Available from: http://www.scielo.br/pdf/ reeusp/v43nspe2/en_a10v43s2.pdf

8. Abu-Saad K, Fraser D. Maternal nutrition and birth outcomes. Epidemiol Rev. 2010; 32(1):5-25.

9. Kalaivani K. Prevalence and consequences of anaemia in pregnancy. Indian J Med Res. 2009;130(5):627-33.
10. Brasil. Ministério da Saúde; Agência Nacional de Vigilância Sanitária. Resolução RDC n. 344, de 13 de dezembro de 2002. Aprova o Regulamento Técnico para a Fortificação das Farinhas de Trigo e das Farinhas de Milho com Ferro e Ácido Fólico, constante do anexo desta Resolução [Internet]. Brasília; 2002 [citado 2014 Jan 22]. Disponível em: http://portal.anvisa.gov.br/wps/wcm/connect/ f851a500474580668c83dc3fbc4c6735/RDC_344_2002. pdf?MOD=AJPERES

11. Fujimori E, Sato APS, Szarfarc SC, Veiga GV, Oliveira VA, Colli $C$, et al. Anemia em gestantes brasileiras antes e após a fortificação das farinhas com ferro. Rev Saúde Pública. 2011;45(6):1027-35.

12. World Health Organization (WHO). Iron deficiency anaemia: assessment, preventing, and control. A Guide for Programme Managers. Geneva: WHO; 2001.

13. Centers for Diseases Control and Prevention (CDC). Current trends $C D C$ criteria for anemia in children and childbearing-age women. MMWR Morb Mortal Wkly Rep. 1989;38(22):400-4.

14. Szarfarc SC, Siqueira AAF, Martins IS. Avaliação da concentração de ferro orgânico em uma população de grávidas. Rev Saúde Pública. 1983;17(3):200-7.

15. Szarfarc SC. Anemia nutricional entre gestantes atendidas em centros de saúde, São Paulo, Brasil. Rev Saúde Pública. 1985;19(5):450-7.

16. Darnton-Hill I, Nalubola R. Fortification strategies to meet micronutrient needs: successes and failures. Proc Nutr Soc. 2002;61(2):231-41. 
17. Tao M, Pelletier DL, Miller DD. The potential effect of iron defortification on iron-deficiency anaemia in the US population. Public Health Nutr. 2007;10(11):1266-73.

18. Szarfarc SC. Políticas públicas para o controle da anemia ferropriva. Rev Bras Hematol Hemoter. 2010;32 Supl. 2:2-8.

19. McLean E, Cogswell M, Egli I, Wojdyla D, Benoist B. Worldwide prevalence of anaemia. WHO Vitamin and Mineral Nutrition Information System, 1993-2005. Public Health Nutr. 2009;12(4):444-54.

20. van Buul EJ, Steegers EA, Jongsma HW, Eskes TK, Thomas $\mathrm{CM}$, Hein PR. Haematological and biochemical profile of uncomplicated pregnancy in nulliparous women; a longitudinal study. Neth J Med. 1995;46(2):73-85.

21. Knight EM, Spurlock BG, Edwards $\mathrm{CH}$, Johnson AA, Oyemade UJ, Cole OJ, et al. Biochemical profile of African American woman during three trimesters of pregnancy and at delivery. J Nutr. 1994;124(6 Suppl):943-53.
22. Milman N, Byg KE, Agger AO. Reference values for hemoglobin and erythrocyte indices during normal pregnancy in 206 women with and without iron supplementation. Acta Obstet Gynecol Scand. 2000;79(2)89-98.

23. Narchi NZ. Prenatal care by nurses in the East Zone of the city of São Paulo - Brazil. Rev Esc Enferm USP [Internet]. 2010 [cited 2014 Jan 22];44(2):266-73. Available from: http://www.scielo.br/pdf/reeusp/v44n2/en_04.pdf

24. Sato APS, Fujimori E. Nutritional status and weight gain in pregnant women. Rev Latino Am Enferm. 2012;20(3):462-8. 